\title{
ESTUDIO DE VALIDACIÓN PRECLÍNICA DEL USO TRADICIONAL ANTI-TUMORAL DE UNCARIA TOMENTOSA (UÑA DE GATO)
}

\author{
Díaz Oreiro, Cecilia ${ }^{1,2}$ y Vargas Arroyo, Mariángela ${ }^{1}$ \\ ${ }^{1}$ Instituto Clodomiro Picado, Facultad de Microbiología, Universidad de Costa Rica, San José, Costa Rica \\ ${ }^{2}$ Departamento de Bioquímica, Escuela de Medicina, Universidad de Costa Rica, San José, Costa Rica
}

\begin{abstract}
Resumen: Uncaria tomentosa ha sido usada en varios países como una medicina anti-inflamatoria y antitumoral, pero debido a sus efectos farmacológicos esta planta ha sido colectada extensivamente y enfrenta la extinción.

A pesar de su uso tradicional anti-tumoral, el extracto acuoso de la corteza de la raíz fue el extracto menos activo. La preparación hidroalcohólica de la corteza de la raíz mostró una $\mathrm{LD}_{50}$ entre 150 y $500 \mu \mathrm{g} / \mathrm{mL}$ y los extractos de las hojas (acuoso e hidroalcohólico) mostraron $\mathrm{LD}_{50}$ tan bajas como $180.1 \mu \mathrm{g} / \mathrm{mL}$.

El índice de selectividad mostró que excepto por las células de astrocitoma y leucémicas, todas las líneas tumorales fueron de 2-8 veces más sensibles a los extractos que las células no-tumorales.

Alcaloides pentaciclicosoxindólicos (mitrafilina, isomitrafilina, uncarina C y uncarina E) están presentes en los extractos y probablemente juegan un papel en los efectos citotóxicos sobre las líneas celulares tumorales. Nuestro estudio sugiere que las raíces de Uncaria tomentosa podrían ser reemplazadas por las hojas para obtener buenos resultados farmacológicos, protegiendo así la planta de la extinción.
\end{abstract}

Palabras clave: Uncaria tomentosa, uña de gato, planta medicinal, anti-tumoral, alcaloides, conservación de plantas 


\title{
PRECLINICAL VALIDATION STUDY OF THE ANTICANCER TRADITIONAL USE OF UNCARIA TOMENTOSA (CAT'S CLAW)
}

\begin{abstract}
Uncaria tomentosa has been widely used in several countries as an anti-inflammatory and antitumoral remedy, but due to its pharmacological effects this plant has been extensively harvested and faces extinction.

Regardless of its traditional anti-tumoral use, root bark water extract was the lesser active extract. Hydroalcoholic preparation of the root bark showed $\mathrm{LD}_{50}$ ranging from 150 to $500 \mu \mathrm{g} / \mathrm{mL}$ and leaf extracts (water and hydroalcoholic) showed $L_{50}$ as low as $180.1 \mu \mathrm{g} / \mathrm{mL}$. Selectivity index showed that except for astrocytoma and leukemia, all tumor cells were 2-8 times more sensitive to the extracts than to nontumorcells.

Oxindole pentacyclic alkaloids (mitraphylline, isomitraphylline, uncarine $\mathrm{C}$ and uncarine $\mathrm{E}$ ) are present in the extracts and they probably play a role in the cytotoxic effect on tumor cell lines.

Our study suggests that $U$. tomentosa roots could be replaced by the leaves in order to obtain good pharmacological results, protecting the plant from extinction.
\end{abstract}

Key words: Uncaria tomentosa, cat's claw, medicinal plant, anticancer, alkaloids, plant conservation

\section{INTRODUCCIÓN}

Uncaria tomentosa ( $U$. tomentosa) is a climbing woody vine, native from the Amazon and Central America rainforests that belongs to the Rubiaceae family. Its root bark aqueous extract or decoction has been widely used in Latin American countries as antiinflammatory and anti-tumoral. This plant has been so widely used that it faces the risk of extinction due to extensive harvesting and deforestation of its natural habitat [1].

Even when $U$. tomentosa is one of the most widely studied medicinal plants [2], the presence of two different chemotypes [3] and the fact that the total amount of the published studies regarding this plant and its potential activities, have been carried out with the Peruvian plant, makes it imperative to do some regional validation studies. The presence of at least 17 different alkaloids in Peruvian $U$. tomentosa has been reported as well as two different botanicallyindistinguishable chemotypes: one containing pentacyclic, and the other containing tetracyclic oxindole alkaloids [3,4]. Interestingly, both types of alkaloids seem to have antagonistic biological properties [5].

There are just a few reports in the literature in which cytotoxicity or antiproliferative activities of this plant extracts on tumor cells, have been tested [6-8] and there is a recent study where in vivo anti-tumoral activity of an hydroalcoholic extract has been carried out in a carcinosarcoma rat model [9]. Pilarski et al. [10], on the other hand, showed that a water $U$. tomentosa extract could be effective against lung carcinoma in mice, whereas hydroalcoholic and dichloromethane extracts were ineffective.

Some recent reports indicate also, that not only the alkaloids could be responsible for the medicinal activities, at least the ones related with the antioxidant properties of the extracts; other compounds such as flavonoids and phenolic acids, for instance, could be also important [11]. Moreover, Sheng et al. [12] reported that since water-soluble $U$. tomentosa extracts did not supposed to contain any significant amounts of alkaloids (less than $0.05 \%$ ), the substances responsible 
for the activities could be other ones such as quinic acid.

However, from a pharmacological point of view, alkaloids are still considered some of the most important secondary metabolites present in this plant. For instance, Garcia Prado and collaborators [4] showed that micromolar concentrations of mitraphylline, one of the pentacyclic oxindole alkaloids present in $U$. tomentosa, are able to inhibit proliferation of two brain tumor cells, a glioma and a neuroblastoma, with $\mathrm{IC}_{50}$ values of 12.3 and $20 \mu \mathrm{M}$ after 30 and $48 \mathrm{hr}$ of treatment, respectively.

In this study, we tested four different extracts of U. tomentosa growing in the Atlantic Region of Costa Rica, two hydroalcoholic and two aqueous preparations from leaves and root bark, on eight different tumor cell lines. Also, we analyzed the presence of pentacyclic oxindole alkaloids in the extracts using HPLC.

\section{MATERIALS AND METHODS}

\section{Chemicals}

HPLC grade acetonitrile was purchased from Merck (Darmstadt, Germany) and monobasic potassium phosphate $\left(\mathrm{KH}_{2} \mathrm{PO}_{4}\right)$ from J.T. Baker Inc. (Phillipsburg, NJ, US). Alkaloid standards, mitraphylline, isomitraphylline, Uncarine $C$ and Uncarine $E$, were purchased from Chromadex, Inc. (Irvine, CA, US). Ultrapure water was obtained from a Simplicity 185 water purification system (Millipore, Molsheim, France). Dulbecco Essential Medium, fetal bovine serum, glutamine and antibiotic/antimycotic solution as well as 3-(4,5-dimethylthiazol-2-yl)-2,5diphenyltetrazolium bromide (MTT) were purchased from Sigma Aldrich Co. (St Louis, Mo, US).

\section{Plant Material and Extract Preparation}

Root bark and leaves of Uncaria tomentosa (Willd.) plants were collected in Cariari de Guápiles, Province of Limón, in the Atlantic region of Costa Rica. A voucher specimen of this plant was deposited at the Herbarium of the Museo Nacional de Costa Rica (No. 2433, CR254451). Plants were dried at room temperature and the extracts were prepared as follow. To prepare the water extract, 0.1 gr of dried leaves and root bark were extracted with 1 liter of distilled water at $70^{\circ} \mathrm{C}$ during $20 \mathrm{~min}$. Then, samples were separated by filtration and the aqueous extract was concentrated under vacuum at $40^{\circ} \mathrm{C}$ and further lyophilized to powder. To obtain the hydroalcoholic extract, 0.1 gr of dried leaves and root bark were extracted with 1 liter of 95\% ethanol during $72 \mathrm{hr}$, then filtered and concentrated under vacuum and lyophilized to powder.

\section{High Performance Liquid Chromatography}

The chromatographic procedure was carried out in an Agilent Technologies 1100 series HPLC system equipped with an UV detector, a manual injector and a chromatographic data management software (ChemStation Data Analysis and Reporting) (Santa Clara, CA, US). Samples were separated in an Aquasil C18 reverse-phase column (150 X 4.6 mmi.d., $5 \mu \mathrm{m}$ particle size) (Thermo Scientific, US) guarded with a Uniguard holder for 4.0/4.6 mm. i.d. (Thermo Scientific, US), using a mobile phase $\mathrm{A}$, consisting of a $10 \mathrm{mM}$ phosphate buffer $\left(\mathrm{KH}_{2} \mathrm{PO}_{4}\right)$, pH 7 and a mobile phase $\mathrm{B}$, consisting of acetonitrile. A gradient was used, in which at first the concentration of B was maintained at 35\% for 17 minutes, then increased to $50 \%$ B over 8 minutes and maintained at $50 \% \mathrm{~B}$ for 5 minutes. The flow rate was set at $0.75 \mathrm{~mL} / \mathrm{min}$, column temperature was kept at $25^{\circ} \mathrm{C}$, and the detection was done at $214 \mathrm{~nm}$.

Peaks in experimental samples were identified by comparison with elution times of alkaloid standards. The standards employed were mitraphylline, isomitraphylline, uncarine $\mathrm{C}$ and uncarine $\mathrm{E}$, previously dissolved in acetonitrile $(1 \mathrm{mg} / \mathrm{mL})$. Dried extracts were dissolved in acetonitrile, $95 \% \mathrm{v} / \mathrm{v}$ ethanol or distilled water at a concentration of $1 \mathrm{mg} / \mathrm{mL}$.

Since the preparations were not alkaloid-rich extracts, but complete water and hydroalcoholic extracts, the HPLC corresponding peaks were not very conspicuous. Therefore, samples were run and peaks with retention times from minute 20 to 35 were pooled. These fractions correspond to the time range of the retention time of standards. Later on, these concentrated pools were run under the same HPLC conditions.

\section{Cell Culture}

Astrocytoma (CCF-STTG1), hepatocellular carcinoma (Hep3B, HepG2), lung large cell carcinoma (H-460), gastric carcinoma (AGS, N-87), colon adenocarcinoma (SW-620), breast carcinoma (MCF-7)

Revista electrónica publicada por el Departamento de Farmacología de la Escuela de Medicina de la Universidad de Costa Rica, 2060 San José, Costa Rica. ${ }^{\circledR}$ All rights reserved. Licensed under a Creative Commons Unported License. 
and kidney epithelial (Vero) cell lines were obtained from American Type Culture Collection (ATCC) or the National Cancer Institute (Frederick, MD, US). Cells were maintained in Dulbecco essential medium supplemented with $10 \%$ fetal bovine serum, $2 \mathrm{mmol} / \mathrm{L}$ of glutamine, $100 \mathrm{IU} / \mathrm{mL}$ of penicillin and amphotericin $\mathrm{B}$ in a $37^{\circ} \mathrm{C}$ humidified incubator under an atmosphere of $7 \% \mathrm{CO}_{2}$ in air. For the experiments, cells were cultured in 96-well plates $(15,000$ cells/well) and allowed to adhere overnight.

\section{Cytotoxicity Assay}

Various concentrations of the extracts (from 100 to $1000 \mu \mathrm{g} / \mathrm{mL}$ ), previously dissolved in $95 \%$ ethanol, were added to the plates in $100 \mu \mathrm{L}$ of fresh medium and incubated for $48 \mathrm{~h}$. After incubation, MTT was added to each well to a final concentration 0.5 $\mathrm{mg} / \mathrm{mL}$ and after $2 \mathrm{~h}$ at $37^{\circ} \mathrm{C}$, medium was carefully removedfrom the plates and 95\% ethanol was added to the wells with the purpose of dissolving formazan crystals. Absorbances were recorded at $570 \mathrm{~nm}$ using a Thermo Scientific Multiskan FC spectrophotometer and viability percentages were calculated, using samples incubated with $95 \%$ ethanol dissolved in culture medium as $100 \%$ viability values. $\mathrm{LD}_{50}$ values were calculated from concentration/viability plots using SlideWrite ${ }^{\circledR}$ Plus 6.1 (Advanced Graphics Software, Inc., Carlsbad, CA, US), to obtain the concentrations able to induce $50 \%$ of cytotoxicity. Three independent experiments performed in triplicate were combined and expressed as $\mathrm{LD}_{50}$.

\section{Statistical Analysis}

Cytotoxicity values were analyzed by unpair tstudent test and ANOVA followed by Tukey's test and $\mathrm{p}<0.05$ was considered statistically significant.

\section{RESULTS}

\section{Cytotoxicity of extracts of $U$. tomentosa on tumor cell lines}

In terms of validation of the traditional antitumoral use of $U$. tomentosa root bark water extract, we could observe that this extract seemed to be the less active extract against all tumor cell lines (Table 1).

The strongest extract for direct cytotoxicity in all the cell lines was the hydroalcoholic preparation of the root bark, showing $\mathrm{LD}_{50}$ ranging from around 150 to $500 \mu \mathrm{g} / \mathrm{mL}$. Interestingly, non-tumoral Vero cells were the most resistant cells to this extract $\left(\mathrm{LD}_{50}\right.$ of 671.3 $\mu \mathrm{g} / \mathrm{mL}$ ), with the exception of astrocytoma cells, which showed no susceptibility at all. The leaf extracts, on the other hand, were both less toxic than the hydroalcoholic root bark preparation, but in this case, the leaf water extract was more toxic than the hydroalcoholic one in cell lines such as K562, H460, Hep3B and AGS. In the other lines tested, the effect was basically the same for both leaf extracts, except for HepG2, where the water extract was less toxic than the hydroalcoholic one. Vero and astrocytoma were completely resistant to both leaf extracts and to the water bark preparation (Table 1).

When we compare the effect of water versus hydroalcoholic extracts in each independent cell line, we found that in the case of the bark, the difference was statistically significant in favour of the hydroalcoholic extract for all the tested cells. In the case of the leaves, no significant differences were observed between water and hydroalcoholic extracts, except in hepatocellular carcinoma cells Hep3B (Table 1).

Selectivity index, a kind of therapeutic index calculated to compare the effect of the extracts on tumor and non-tumor cell lines, showed differences that range from 2 to 8 for almost all the cell types, which indicates that the extracts were more than two times more toxic on tumor cells. In some cases, such as liver and colon carcinoma cells, the values obtained for leaf extracts were higher than 4.5 and up to 8.3 times more toxic (Table 2). 
Table \# 1. Citotoxicity expressed as $\mathrm{LD}_{50}(\mu \mathrm{g} / \mathrm{mL})$ of hydroalcoholic and water extracts of $U$. tomentosa.

\begin{tabular}{|l|c|c|c|c|}
\hline \multicolumn{1}{|c|}{$\begin{array}{c}\text { Cell } \\
\text { line/LD }\end{array}$} & $\begin{array}{c}\text { Hydroalcoholic } \\
\text { extract } \\
\text { (leaves) }\end{array}$ & $\begin{array}{c}\text { Hydroalcoholic } \\
\text { extract } \\
\text { (rootbark) }\end{array}$ & $\begin{array}{c}\text { Water extract } \\
\text { (leaves) }\end{array}$ & $\begin{array}{c}\text { Water extract } \\
\text { (rootbark) }\end{array}$ \\
\hline K562 (leukemia) & $958.8 \pm 93.8$ & $497.1 \pm 71.5$ & $772.2 \pm 38.3$ & $>1500$ \\
\hline HepG2 (liver) & $490.6 \pm 110.6$ & $226.7 \pm 12.9$ & $732.5 \pm 266.8$ & $>1500$ \\
\hline H460 (lung) & $600.2 \pm 183.2$ & $278.1 \pm 56.8$ & $350.9 \pm 70.7$ & $1286.5 \pm 213.5$ \\
\hline Hep3B (liver) & $331.3 \pm 25.3$ & $152.2 \pm 7.3$ & $180.1 \pm 13.0$ & $355.9 \pm 52.5$ \\
\hline $\begin{array}{l}\text { Vero (normal } \\
\text { epithelial) }\end{array}$ & $>1500$ & $671.3 \pm 153.5$ & $>1500$ & $>1500$ \\
\hline $\begin{array}{l}\text { CCF-STTG1 } \\
\text { (astrocytoma) }\end{array}$ & $>1500$ & $>1500$ & $>1500$ & $>1500$ \\
\hline SW620 (colon) & $285.4 \pm 36.6$ & $200.0 \pm 38.3$ & $262.8 \pm 25.7$ & $>1500$ \\
\hline MCF7 (breast) & $508.0 \pm 2.0$ & $281.6 \pm 31.1$ & $512.0 \pm 173.0$ & $>1500$ \\
\hline AGS (stomach) & $405.1 \pm 45.3$ & $189.6 \pm 18.9$ & $355.8 \pm 43.1$ & $>1500$ \\
\hline
\end{tabular}

*Three independent experiments were performed in triplicate and the results are expressed as mean \pm SE.

Table \# 2. Selectivity index.

\begin{tabular}{|l|c|c|c|c|}
\hline \multicolumn{1}{c|}{$\begin{array}{c}\text { Cell } \\
\text { line/LD }\end{array}$} & $\begin{array}{c}\text { Hydroalcoholic } \\
\text { extract } \\
\text { (leaves) }\end{array}$ & $\begin{array}{c}\text { Hydroalcoholic } \\
\text { extract } \\
\text { (rootbark) }\end{array}$ & $\begin{array}{c}\text { Water extract } \\
\text { (leaves) }\end{array}$ & $\begin{array}{c}\text { Water extract } \\
\text { (rootbark) }\end{array}$ \\
\hline K562 (leukemia) & $>1.6$ & 1.4 & $>1.9$ & 1.0 \\
\hline HepG2 (liver) & $>3.1$ & 3.0 & $>2.0$ & $>1.0$ \\
\hline H460 (lung) & $>2.5$ & 2.4 & $>4.3$ & $>4.2$ \\
\hline Hep3B (liver) & $>4.5$ & 4.4 & 1.0 & 1.0 \\
\hline CCF-STTG1 & 1.0 & $<0.4$ & $>8.3$ & 1.0 \\
\hline (astrocytoma) & $>5.3$ & 3.4 & $>5.7$ & 1.0 \\
\hline SW620 (colon) & $>3.0$ & 2.4 & $>2.9$ & 1.0 \\
\hline AGS7 (breast) & $>3.7$ & 3.5 & $>4.2$ & \\
\hline
\end{tabular}

*Ratio calculated between $\mathrm{LD}_{50}$ of each tumor cell line and $\mathrm{LD}_{50}$ of VERO cells.

\section{Determination of pentacyclic oxindole alkaloids in extracts of $U$. tomentosa}

The presence of four $U$. tomentosa pentacyclic main oxindole alkaloids was determined on hydroalcoholic and water extracts of bark and leaves using commercial standards for identification. Three different solvents were used to dissolve the extracts before HPLC separation, since they were made in different solvents and solubility could vary between them. Acetonitrile was used, since it was the mobile Revista electrónica publicada por el Departamento de Farmacología de la Escuela de Medicina de la Universidad de Costa Rica, 2060 San José, Costa Rica. ${ }^{\circledR}$ All rights reserved. Licensed under a Creative Commons Unported License. Contáctenos: rev.med.ucr@gmail.com. Tel: (506) 25-11 4492, Fax: 25-11-4489. 


\section{DISCUSSION}

When a plant is used for medicinal purposes, it is very important to consider which chemotype is being used, since most of the times, no phenotypic differences are observed between these specimens but strong differences are evident in terms of the secondary metabolites they contain. In Costa Rica, for example, $U$. tomentosa is a widely used medicinal plant which in contrast to the one growing in Peru, has not been characterized in terms of the chemical composition, or validated according to its traditional medicinal uses.

Interestingly, this study did not clearly validate, at the preclinical level, the anticancer effect of the water extract of $U$. tomentosa root bark, the one used in traditional medicine. It is clear that to get better direct anti-tumoral activity, a hydroalcoholic extract should be prepared, this in terms of cytotoxicity on all the cell lines tested (except from brain tumor cells, which were completely resistant to all the extracts) and also the presence of pentacyclic oxindole alkaloids. Even when the effect of these extracts was not very high (lowest $\mathrm{LD}_{50}$ at $48 \mathrm{hr}$ of treatment was around $150 \mu \mathrm{g} / \mathrm{mL}$ ), therapeutic index was potentially good, since Vero cells, which are non-tumoral, seem to be very resistant to the extracts (see selectivity indexes in Table 2). Moreover, in terms of plant conservation, an aqueous leaf extract could be even a better option, since for most tumor cells, good cytotoxicity results and better therapeutic index could be obtain without the need to kill the plant by extensive recollection of the roots and using a decoction, which is the easiest way to prepare the plant for drinking.

In the case of the resistance of brain tumor cells to the extracts, an interesting study [4] showed that one of the oxindole pentacyclic alkaloids present in this plant, mitraphylline, at micromolar concentrations, could inhibit the growth of glioma and neuroblastoma cell lines after 30-48 hr of treatment. Moreover, our studies with the extracts do not support these results obtained on brain tumor cells with the pure alkaloid, since astrocytoma cells were very resistant to the extracts.

In terms of the presence of alkaloids in the $U$. tomentosa extracts (bark from Peruvian plant) and their cytotoxic effects, Pilarski and collaborators $[8,10]$ have reported differences based on different solvent extractions. They reported a high correlation between total oxindole alkaloid content and anti-proliferative properties of the extracts, with $\mathrm{IC}_{50}$ going from 23.57 to
$1000 \mu \mathrm{g} / \mathrm{mL}$. The extracts prepared with $96 \%$ ethanol or dichloromethane were the ones showing higher toxicity on the cells (and the higher alkaloid content), whereas the lowest toxicity was obtained with water extracts [10]. However, something very interesting of this study was that when they tested the in vivo anticancer activity on mice bearing Lewis lung carcinoma treated for 21 days, the water extract was the one showing an effect, the opposite to what they obtained when tumor cells were treated in vitro. In this study, authors incubated the cells with the extracts for $72 \mathrm{hr}$, which could explain the stronger activities found comparing to our results and they also used a different method to determine toxicity (or growth inhibition). Also, differences between plants growing in Peru and Costa Rica could exist.

Since one of the first activities reported for $U$. tomentosa extracts was an immunomodulatory effect, probably through $\mathrm{TNF} \alpha$, direct cell toxicity does not necessarily correlates with in vivo anti-cancer effect. And also, other $U$. tomentosa non-alkaloid components have been reported as well which could be responsible for some of the extract activities [11,13].

Even when we did not quantify the oxindole alkaloid concentrations, we observed that both, hydroalcoholic and water extracts may contained pentacyclic mitraphyllline, isomitraphylline, uncarine C and uncarine E. Moreover, as the literature reported, hydroalcoholic bark root extract seem to be the one that more clearly shows their presence and the most toxic one for tumor cells. However we suggest that, in the case of the anticancer traditional use, a water leaf extract could be more efficient than the water bark one, at least for the direct cytotoxic activities against tumors such as lung, liver and colon carcinomas. However, more in vivo studies should be performed to further validate the traditional effects of these extracts.

$U$. tomentosa and many other medicinal plants are being destroyed at very high rate and face the threat of extinction due to indiscriminate harvesting. For this reason, it is suggested that if this plant continues to be extensively used as medicinal, the leaves instead of the roots should be used to prepare the extracts, in order to obtain some of the pharmacological effects attributed to this interesting plant. 


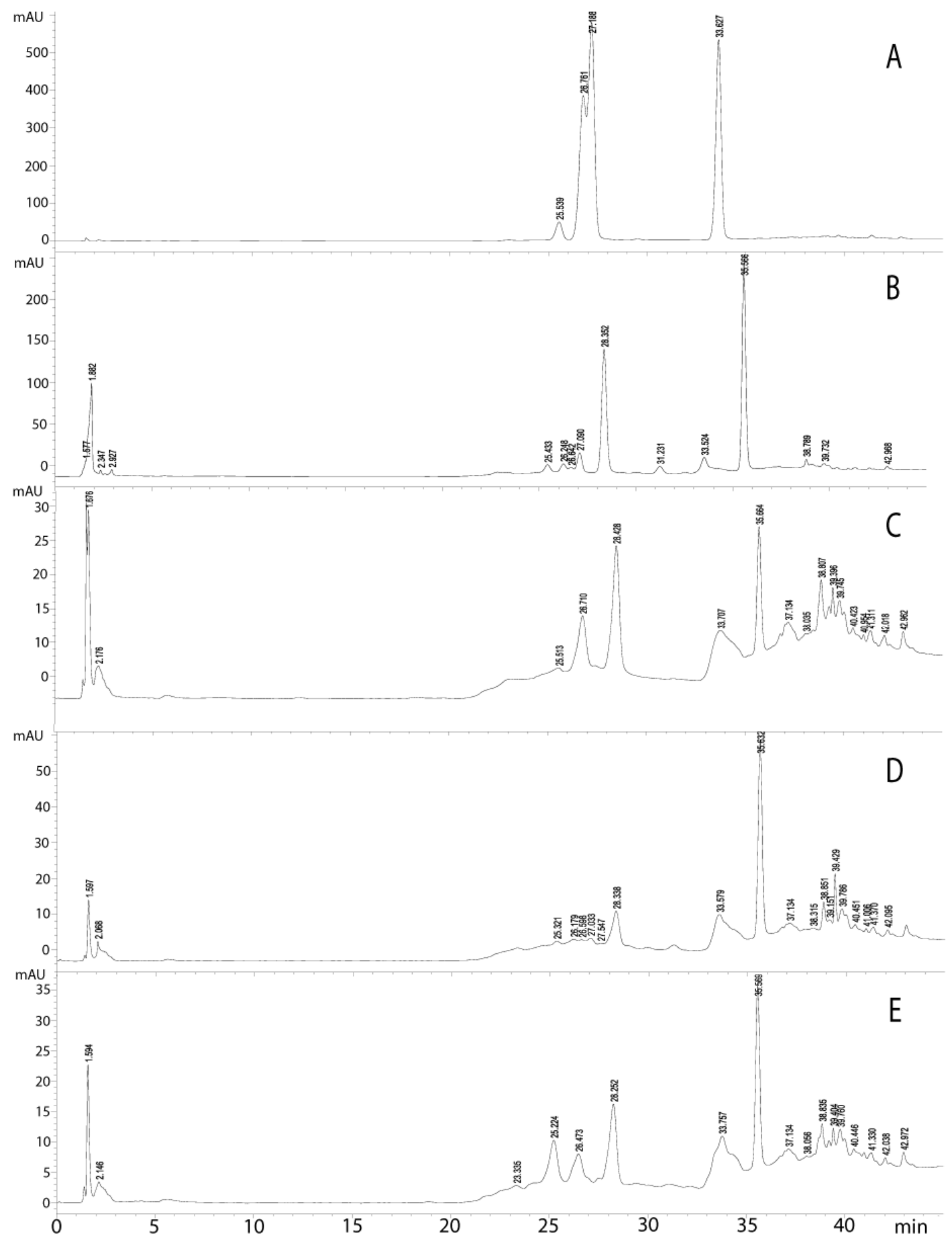

Figure 1. HPLC chromatogram of pools of alkaloid-containing fractions of $U$. tomentosa extracts. A. Alkaloid standards: mitraphylline (25.539 min), isomitraphylline (26.761 min), uncarine C (27.188 $\mathrm{min})$ and uncarine E (33.627 $\mathrm{min})$. B. Root bark hydroalcoholic extract. C. Leaf hydroalcoholic extract. D. Root bark water extract. E. Leaf water extract. For the HPLC analysis, sample A was dissolved in acetonitrile, and samples B, C, D and E dissolved in 95\% v/v ethanol. 


\section{ACKNOWLEDGEMENTS}

The authors are grateful to Fondo del Sistema de CONARE (Project No. 422-A7-147) and Vicerrectoría de Investigación, Universidad de Costa Rica (Project No. 422-A8-227) for financial support and to Professor J.F. Cicció (CIPRONA, UCR) for his important comments and the preparation of the extracts. We also thank the colleagues from Instituto Tecnológico de Costa Rica that participated in Project No. 422-A7-147 for harvesting and classification of the plant.

\section{REFERENCES}

1. Pereira, R de C.A., Valente, L.M.M., Pinto, J.E.B.P., Bertolucci S.K.V., Bezerra, G.M., Alves, F.F., dos Santos, P.F.P., Benevides, P.J.C., Siani, A.C., Rosario, S.L., Mazzei, J.L., d'Avila, L.A., Gomes, L.N.F., de Aquino-Neto, F.R., Emmerick, I.C.M. y Carvalhaes, S.F. In vitro cultivated Uncaria tomentosa and Uncaria guianensis with determination of the pentacyclic oxindole alcakaloid contents and profiles. J. Braz. Chem. Soc. 2008;19: 1193-1200.

2. Heitzman, M.E., Neto, C.C., Winiarz, E. y Waisberg, A.J., Hammond, G.B. Ethnobotany, phytochemistry and pharmacology of Uncaria (Rubiaceae). Phytochemistry 2005;66: 5-29.

3. Reinhard, K.H. Uncaria tomentosa (Willd.) D.C.: cat's claw, uña de gato, or savéntaro. J. Alternative and Complementary Medicine. 1999;5: 143-151.

4. García Prado, E., García Giménez, M.D., De la Puerta Vázquez, R., Espartero Sánchez J.L. y Sáenz Rodríguez M.T. Antiproliferative effects of mitraphylline, a pentacyclic oxindole alcaloid of Uncaria tomentosa on human glioma and neuroblastoma cell lines. Phytomedicine 2007;14: 280-84.

5. Keplinger, K. Laus, G., Wurm, M., Dierich, M.P. y Teppner, H. Uncaria tomentosa (Willd.) DC. Ethnomedicinal use and new pharmacological, toxicological and botanical results. Journal of Ethnopharmacology, 1999;64:23-34.

6. Bacher, N., Tiefenthaler, M., Sturm, S., Stuppner, H., Ausserlechner, M.J., Kofler, R. y Konwalinka, G. Oxindole alkaloids from Uncaria tomentosa induce apoptosis in proliferating, G0/G1-arrested and bcl-2expressing acute lymphoblastic leukemia cells. British J. Haematol. 2005;132: 615-22.

7. De Martino, L., Silva Martinot, J.L.S., Franceschelli, S., Leone, A., Pizza, C. y De Feo, V. Proapoptotic effect of Uncaria tomentosa extracts. Journal of Ethnopharmacology 2006;107:91-94.

8. Pilarski, R., Poczekaj-Kostrzewska, M., Ciesiolka, D., Szyfter, K. y Gulewicz, K. Antiproliferative activity of various Uncaria tomentosa preparations on HL-60 promyelocytic leukemia cells. Pharmacological Reports 2007; 59: 565-72.

9. Dreifuss A.A., Bastos-Pereira A.L., Ávila, T.V., da Silva Soley, B., Rivero, A.J., Aguilar J.L. y Acco, A. Antitumoral and antioxidante effects of a hydroalcoholic extract of cat's claw (Uncaria tomentosa) (Willd. Ex Roem. \& Schult) in an in vivo carcinosarcoma model. Journal of Ethnopharmacology 2010;130, 127-133.

10. Pilarski, R., Filip, B., Wietrzyk, J., Kuras M. y Gulewicz, K. Anticancer activity of the Uncaria tomentosa (Willd.) DC. preparations with different oxindole alkaloid composition. Phytomedicine 2010;17: 11339.

11. Amaral, S., Mira, L., Nogueira J.M.F. y Pereira da Silva, A., Florencio M.H. Plant extracts with antiinflammatory properties-A new approach for characterization of their bioactive compounds and establishment of structure-antioxidant activity relationships. Bioorganic \& Medicinal Chemistry 2009;17: 1876-83.

12. Sheng, Y., Akesson, C., Holmgren, K., Bryngelsson C., Giamapa, V. y Pero, R.W. An active ingredient of Cat's claw water extracts identification and efficacy of quinic acid. Journal of Ethnopharmacology 2005;96:577-584.

13. Sandoval, M., Okuhama N.N., Zhang, X.J., Condezo, L.A., Lao, J., Angeles, F.M., Musah, R.A., Bobrowski, P. y Miller, M.J. Anti-inflammatory and antioxidant activities of cat's claw (Uncaria tomentosa and Uncaria guianensis) are independent of their alkaloid content. Phytomedicine 2002;9: 324-37.

\section{INFORMACION DE AUTOR:}

\author{
Cecilia Díaz Oreiro \\ Fax: (506) 25115209 \\ E-mail: cecilia.diaz@ucr.ac.cr
}

